\title{
Cellular prion protein is required for neuritogenesis: fine-tuning of multiple signaling pathways involved in focal adhesions and actin cytoskeleton dynamics
}

\author{
This article was published in the following Dove Press journal: \\ Cell Health and Cytoskeleton \\ 10 July 2013 \\ Number of times this article has been viewed
}

\author{
Aurélie Alleaume-Butaux ${ }^{1,2}$ \\ Caroline Dakowski ${ }^{1,2}$ \\ Mathéa Pietri ${ }^{1,2}$ \\ Sophie Mouillet-Richard ${ }^{1,2}$ \\ Jean-Marie Launay,4 \\ Odile Kellermann ${ }^{1,2}$ \\ Benoit Schneider ${ }^{1,2}$ \\ 'INSERM, UMR-S 747, ${ }^{2}$ Paris \\ Descartes University, Sorbonne Paris \\ Cité, UMR-S 747, ${ }^{3}$ Public Hospital of \\ Paris, Department of Biochemistry, \\ INSERM UMR-S 942, Lariboisière \\ Hospital, Paris, France; ${ }^{4}$ Pharma \\ Research Department, Hoffmann La \\ Roche Ltd, Basel, Switzerland
}

\begin{abstract}
Neuritogenesis is a dynamic phenomenon associated with neuronal differentiation that allows a rather spherical neuronal stem cell to develop dendrites and axon, a prerequisite for the integration and transmission of signals. The acquisition of neuronal polarity occurs in three steps: (1) neurite sprouting, which consists of the formation of buds emerging from the postmitotic neuronal soma; (2) neurite outgrowth, which represents the conversion of buds into neurites, their elongation and evolution into axon or dendrites; and (3) the stability and plasticity of neuronal polarity. In neuronal stem cells, remodeling and activation of focal adhesions (FAs) associated with deep modifications of the actin cytoskeleton is a prerequisite for neurite sprouting and subsequent neurite outgrowth. A multiple set of growth factors and interactors located in the extracellular matrix and the plasma membrane orchestrate neuritogenesis by acting on intracellular signaling effectors, notably small G proteins such as RhoA, Rac, and Cdc42, which are involved in actin turnover and the dynamics of FAs. The cellular prion protein $\left(\mathrm{PrP}^{\mathrm{C}}\right)$, a glycosylphosphatidylinositol (GPI)-anchored membrane protein mainly known for its role in a group of fatal neurodegenerative diseases, has emerged as a central player in neuritogenesis. Here, we review the contribution of $\mathrm{PrP}^{\mathrm{C}}$ to neuronal polarization and detail the current knowledge on the signaling pathways fine-tuned by $\mathrm{PrP}^{\mathrm{C}}$ to promote neurite sprouting, outgrowth, and maintenance. We emphasize that $\mathrm{PrP}^{\mathrm{C}}$-dependent neurite sprouting is a process in which $\operatorname{PrP}^{\mathrm{C}}$ governs the dynamics of FAs and the actin cytoskeleton via $\beta 1$ integrin signaling. The presence of $\mathrm{PrP}^{\mathrm{C}}$ is necessary to render neuronal stem cells competent to respond to neuronal inducers and to develop neurites. In differentiating neurons, $\operatorname{PrP}^{\mathrm{C}}$ exerts a facilitator role towards neurite elongation. This function relies on the interaction of $\mathrm{PrP}^{\mathrm{C}}$ with a set of diverse partners such as elements of the extracellular matrix, plasma membrane receptors, adhesion molecules, and soluble factors that control actin cytoskeleton turnover through Rho-GTPase signaling. Once neurons have reached their terminal stage of differentiation and acquired their polarized morphology, $\operatorname{PrP}^{\mathrm{C}}$ also takes part in the maintenance of neurites. By acting on tissue nonspecific alkaline phosphatase, or matrix metalloproteinase type $9, \operatorname{PrP}^{\mathrm{C}}$ stabilizes interactions between neurites and the extracellular matrix.
\end{abstract}

Keywords: prion, neuronal differentiation, neurite sprouting, neurite outgrowth, signaling, multiprotein complexes

\section{Introduction}

Neuritogenesis is a complex morphological phenomena accompanying neuronal differentiation. Neuritogenesis relies on the initial breakage of the rather spherical symmetry of neuroblasts and the formation of buds emerging from the postmitotic 
neuronal soma. ${ }^{1}$ Buds then evolve into neurites, which later convert into an axon or dendrites. ${ }^{2}$ At the distal tip of neurites, the growth cone integrates extracellular signals and guides the neurite to its target. The acquisition of neuronal polarity depends on deep modifications of the neuroblast cytoskeleton characterized by the remodeling and activation of focal adhesions (FAs) and localized destabilization of the actin network in the neuronal sphere. ${ }^{1,3,4}$ Actin instability in unpolarized neurons allows neurite sprouting, ie, the protrusion of microtubules, and subsequent neurite outgrowth. ${ }^{5}$ Once the neurite is formed, actin microfilaments recover their stability and exert a sheathed action on neurites, a dynamic process necessary for the maintenance and integrity of neurites. ${ }^{6}$

A combination of extrinsic and intrinsic cues pilots the architectural and functional changes in FAs and the actin network along neuritogenesis. This process includes neurotrophic factors (nerve growth factor, brain derived neurotrophic factor, neurotrophin, ciliary neurotrophic factor, glial derived neurotrophic factor) and their receptors, ${ }^{7-12}$ protein components of the extracellular matrix (ECM) (laminin, vitronectin, fibronectin), ${ }^{13-15}$ plasma membrane integrins and neural cell adhesion molecules (NCAM), ${ }^{5,16}$ and intracellular molecular protagonists such as small $\mathrm{G}$ proteins (RhoA, Rac, Cdc42) and their downstream targets. ${ }^{17,18}$

The cellular prion protein $\left(\mathrm{PrP}^{\mathrm{C}}\right)$, whose conversion into pathogenic prions $\left(\mathrm{PrP}^{\mathrm{Sc}}\right)$ is at the root of transmissible spongiform encephalopathies, a group of neurodegenerative diseases affecting both animals (scrapie in sheep, bovine spongiform encephalopathy in cattle) and humans (Creutzfeldt-Jakob disease and its variant, Gerstmann-Sträussler-Scheinker), ${ }^{19}$ has been shown to take part in neuronal differentiation and notably to influence neuritogenesis.

$\operatorname{PrP}^{\mathrm{C}}$ expression starts early, during murine embryogenesis (E8.5). ${ }^{20}$ In adult tissues, $\operatorname{PrP}^{\mathrm{C}}$ is present in virtually all cell types and is most abundantly expressed in neurons. It is located at the outer leaflet of the plasma membrane, to which it is anchored via a glycosylphosphatidylinositol (GPI) moiety. ${ }^{21}$ Because $\mathrm{PrP}^{\mathrm{C}}$ is subject to diverse post-translational modifications, including heterogeneous glycosylations on two Asn residues and proteolytic cleavages, a variety of $\mathrm{PrP}^{\mathrm{C}}$ isoforms exists at the cell surface. As for numerous GPI-anchored proteins, $\operatorname{PrP}^{\mathrm{C}}$ distributes in detergent-resistant microdomains, ${ }^{22-25}$ ie, lipid-rafts or caveolae, of the plasma membrane, known to act as signal transduction platforms. ${ }^{26,27}$ The recruitment of $\mathrm{PrP}^{\mathrm{C}}$ within raft multimolecular complexes and interaction with several partners ${ }^{21}$ fits in with the notion that $\mathrm{PrP}^{\mathrm{C}}$ is associated with signaling events and behaves as a receptor or co-receptor. Indeed, in 2000, our work allowed us to assign a signaling function to $\mathrm{Pr}^{\mathrm{C}}$ in bioaminergic neurons by showing that $\operatorname{PrP}^{\mathrm{C}}$ controls p59Fyn tyrosine kinase activity through interaction with the caveolin-1 membrane protein. ${ }^{28}$ During the last decade, signaling targets downstream from $\mathrm{PrP}^{\mathrm{C}}$ have been identified in neuronal as well as nonneuronal cells. These include PI3 (phosphoinositide-3) kinase, protein kinase C (PKC), NADPH oxidase, extracellular regulated kinases $1 / 2$ mitogen activated protein kinases, cAMP Responsive Element Binding (CREB) transcription factor, $\mathrm{TNF} \alpha$ converting enzyme, $\mathrm{Ca}^{2+}$ and protein kinase $\mathrm{A}$ (PKA) ${ }^{29-34}$ Beyond its own signaling activity, $\mathrm{PrP}^{\mathrm{C}}$ is also assumed to exert the role of a scaffolding protein regulating the assembly of various interactors and signaling modules in rafts. ${ }^{21}$ According to the cellular context and local environment (lipid-raft), $\operatorname{PrP}^{\mathrm{C}}$ interacts with various partners and thereby exerts a wide array of functions, dealing with cell adhesion, stress protection, stem cell proliferation and differentiation, and homeostasis of neurons and nonneuronal cells. ${ }^{21,35-38}$ Here, we review the current knowledge on the contribution of $\mathrm{PrP}^{\mathrm{C}}$ to neuritogenesis focusing on how $\mathrm{PrP}^{\mathrm{C}}$ takes part in the three steps of neuritogenesis: (1) neurite sprouting; (2) neurite outgrowth; and (3) neurite maintenance.

\section{PrPc contribution to neurite sprouting: regulatory function of focal adhesions and actin dynamics via integrins Neurite sprouting depends on an optimal concentration of $\mathrm{PrPC}$ expression in neuronal stem cells}

The involvement of $\mathrm{PrP}^{\mathrm{C}}$ in the initial phase of neuritogenesis is supported by the observation that siRNA-mediated silencing of $\mathrm{PrP}^{\mathrm{C}}$ in the $1 \mathrm{C} 11$ cell line or $\mathrm{PC} 12$ cells (PrP $\mathrm{P}^{\text {null}}$-cells) impairs the sprouting of neurites accompanying neuronal differentiation. ${ }^{15}$ The $1 \mathrm{C} 11$ cell line behaves as a neuroepithelial progenitor, which lacks neuron-associated functions and acquires, upon differentiation, the overall functions of serotonergic $\left(1 \mathrm{C} 11^{5-\mathrm{HT}}\right)$ or noradrenergic $\left(1 \mathrm{C} 11^{\mathrm{NE}}\right)$ neurons in 4 days or 12 days, respectively. ${ }^{39}$ Along the two bioaminergic differentiation programs, almost $100 \%$ of $1 \mathrm{C} 11$ neuronal stem cells develop bipolar extensions. Neurite formation starts 3 to 6 hours after exposure to neuronal inducers. At the end of the serotonergic program (1C1 $1^{5-\mathrm{HT}}$, day 4$)$, neurites reach $\sim 5$-fold the length of the small ovoid cell body. With fully differentiated 
noradrenergic cells $\left(1 \mathrm{C} 11^{\mathrm{NE}}\right.$, day 12$)$, neurites are shorter, thicker, and widely branched on a pyramidal cell body. Of note, $1 \mathrm{C} 11$ progenitors as well as their neuronal progenies endogenously express $\mathrm{PrP}^{\mathrm{C}}$ at similar levels. ${ }^{40}$ The impairment of neurite sprouting in $\mathrm{PrP}^{\text {null }}-1 \mathrm{C} 11$ neuronal stem cells strictly depends on the absence of $\mathrm{PrP}^{\mathrm{C}}$ since the reintroduction of $\operatorname{PrP}^{\mathrm{C}}$ in a $\mathrm{PrP}^{\text {null }}$ context restores neuritogenesis and neuronal differentiation. However, we should note that restoration of neurite sprouting can be observed only when $\mathrm{PrP}^{\text {null }}$ cells re-express $\mathrm{PrP}^{\mathrm{C}}$ to a level similar to that of $1 \mathrm{C} 11$ parental cells. Precursor cells that overexpress or underexpress $\mathrm{PrP}^{\mathrm{C}}$ fail to develop neurites ${ }^{15}$ and to differentiate in response to neuronal inducers. This suggests that the competence of $1 \mathrm{C} 11$ neuronal stem cells to respond to neuronal inducers and to engage in a differentiation program depend on a concentration window of $\operatorname{PrP}^{\mathrm{C}}$ expression. In line with this idea, Watanabe et al recently reported that neurite sprouting and outgrowth in $\mathrm{N} 2 \mathrm{a}$ cells is influenced by $\operatorname{PrP}^{\mathrm{C}}$ expression level. ${ }^{41}$

Such a drastic impact of $\mathrm{PrP}^{\mathrm{C}}$ depletion on neuritogenesis has never been described before and contrasts with the lack of major phenotypic abnormalities in $\mathrm{PrP}^{\mathrm{C}}$ knockout mice. The absence of an obvious developmental phenotype, regarding neurite initiation and outgrowth in PrP knockout mice, ${ }^{35}$ supports the hypothesis that another host-encoded protein is able to compensate for the lack of $\operatorname{PrP}^{\mathrm{C}}$ very early during embryogenesis. ${ }^{42,43}$ That $\mathrm{PrP}^{\mathrm{C}}$ plays a key role during embryogenesis is supported by the work of MalagaTrillo et al, who describe a strong PrP loss-of-function in zebrafish embryos, characterized by the loss of embryonic cell adhesion and arrested gastrulation. ${ }^{44}$ Injection of either zebrafish or mouse PrP mRNAs can partially rescue this knockdown phenotype, further indicating conserved PrP functions in vertebrate embryogenesis. ${ }^{44}$

\section{Negative regulatory function of $\operatorname{PrPC}$ towards $\beta I$ integrins allows neurite sprouting}

The impairment of neurite sprouting in $\mathrm{PrP}^{\mathrm{C}}$-depleted $1 \mathrm{C} 11$ ectodermal stem cells and $\mathrm{PC} 12$ cells revealed that $\mathrm{PrP}^{\mathrm{C}}$ exerts a negative regulatory function towards $\beta 1$ integrins: (1) $\operatorname{PrP}^{\mathrm{C}}$ deficiency is associated with a clustering of $\beta 1$ integrins and a raise in $\beta 1$ integrin signaling activity; (2) antibody-mediated neutralization of $\beta 1$ integrins partly rescues neuritogenesis in $\operatorname{PrP}^{\text {null }}-1 \mathrm{C} 11$ cells $;{ }^{15}$ and (3) manganese-induced $\beta 1$ integrin overactivation in $\mathrm{PrP}^{\mathrm{C}}$ expressing $1 \mathrm{C} 11$ neuronal stem cells impairs neurite sprouting (our unpublished data).
How the sole presence of $\operatorname{PrP}^{\mathrm{C}}$ is sufficient to limit $\beta 1$ integrin aggregation and modulate $\beta 1$ integrin activation remains enigmatic. The activation of integrins relies on deep structural modifications, ie, the acquisition of an extended conformation pointing towards the extracellular space and changes in the orientation of integrin transmembrane domains allowing the recruitment of vinculin and talin adaptors. ${ }^{45}$ Because $\operatorname{PrP}^{\mathrm{C}}$ interacts with $\beta 1$ integrins, ${ }^{46}$ one possibility is that $\operatorname{PrP}^{\mathrm{C}}$ would restrict the conformational changes associated with $\beta 1$ integrin activation. Alternatively, the regulatory function of $\operatorname{PrP}^{\mathrm{C}}$ towards $\beta 1$ integrins may operate within and/or just beneath the plasma membrane. As mentioned, $\operatorname{PrP}^{\mathrm{C}}$ may act in rafts as a scaffolding protein interacting with partners whose identity depends on the cell context. ${ }^{21}$ Through stoichiometric interactions, $\operatorname{PrP}^{\mathrm{C}}$ can modulate the signaling activity of its partners in lipid-rafts, underlying the involvement of $\operatorname{PrP}^{\mathrm{C}}$ in the cell adaptative response (ie, migration, adhesion, cell division, stress protection and so on) to diverse stimuli. ${ }^{21}$ This specific regulatory function of $\operatorname{PrP}^{\mathrm{C}}$ possibly relies on its interaction with the membrane protein caveolin-1..$^{28,47,48}$ The recruitment to rafts and the increase in signaling activity of $\beta 1$ integrins (ie, activation of Src kinases, focal adhesion kinase [FAK], and paxillin) were also shown to depend on caveolin-1. ${ }^{49,50}$ Therefore, by interacting with caveolin-1, we may propose that $\operatorname{PrP}^{\mathrm{C}}$ controls the level of caveolin- 1 bioavailable for $\beta 1$ integrin recruitment and activation. ${ }^{47}$ Disruption of the $\mathrm{PrP}^{\mathrm{C}} /$ caveolin-1 contact upon $\operatorname{PrP}^{\mathrm{C}}$ silencing would authorize the redistribution and interaction of caveolin- 1 with $\beta 1$ integrins. This would favor the clustering of $\beta 1$ integrins and their engagement in highly functional signaling complexes ${ }^{49}$ that block neurite sprouting.

\section{By controlling $\beta I$ integrin clustering and activity, $\operatorname{PrPC}$ optimizes the dynamics of focal adhesions and actin cytoskeleton}

The initiation of neurite formation relies on the recruitment and assembly of FAs with high turnover rates (Figure 1). In $\mathrm{PrP}^{\mathrm{C}}$-deficient precursor cells, the increased activity of FAK and Src kinases, ${ }^{15,51}$ two direct targets of $\beta 1$ integrin signaling, ${ }^{52}$ associated with the overphosphorylation of the FA component paxillin on Tyr31 and Tyr $118,{ }^{15}$ enhance the stability of FAs and slow down their turnover. ${ }^{53}$ Of note, neurite sprouting and outgrowth depend on the constant spatiotemporal regulation of FA stability in the growth cone: ${ }^{54}$ (1) excessive instability of FAs at the front of the growth cone hinders progression of the distal region; and (2) high stability of FAs at the end of the growth cone impairs the 

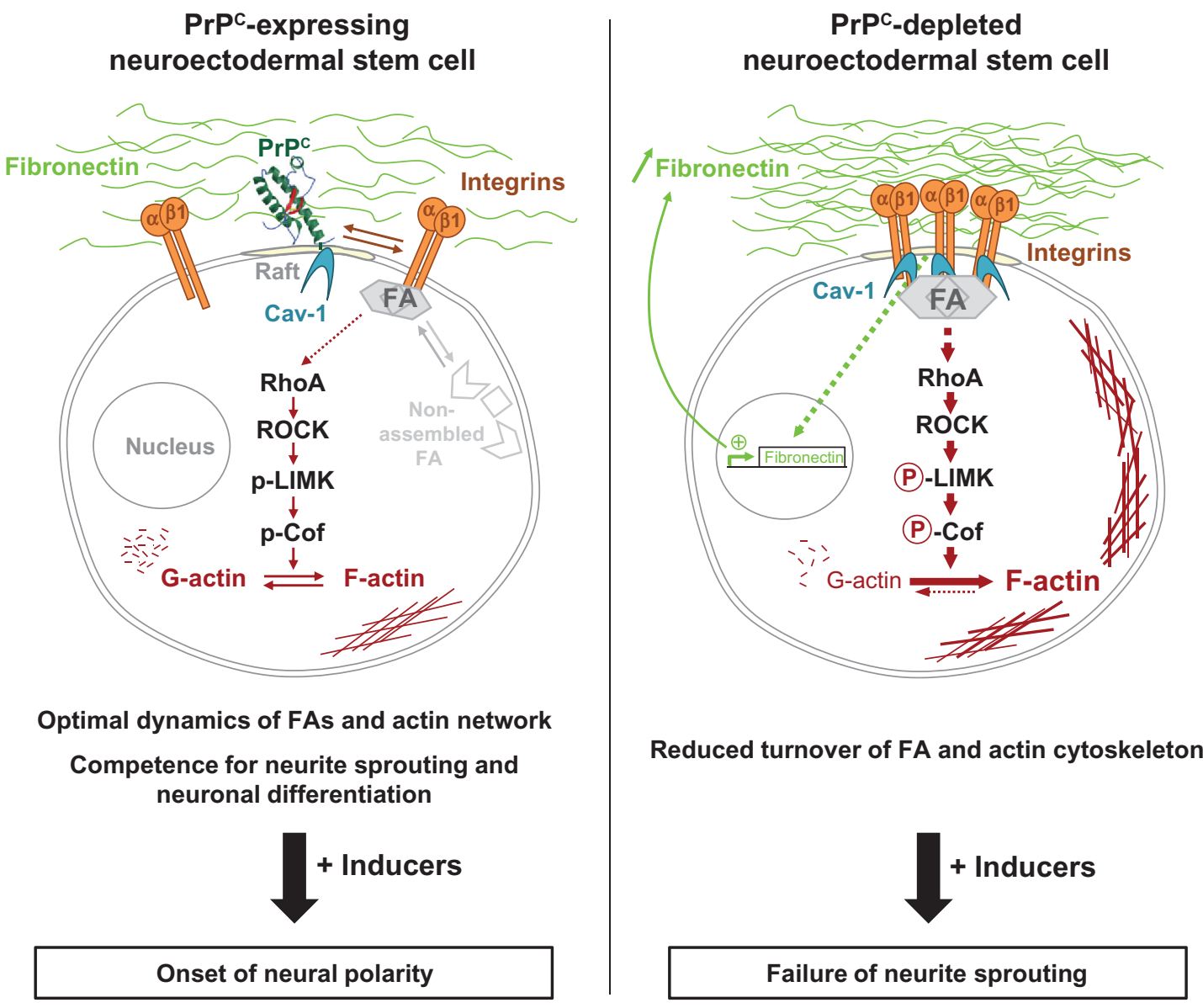

Figure I PrPc depletion in neuroectodermal stem cells impairs neurite sprouting and differentiation. In PrPC expressing neuroectodermal stem cells, PrPC exerts a negative regulatory function towards the clustering and activation of $\beta I$ integrins, which optimizes the dynamics of FAs and the actin network. This regulatory role of PrPC supports cell competence for neurite sprouting and neuronal differentiation. In the absence of PrPC, clustering and activation of $\beta$ I integrins reduce turnover of FAs and overactivate the RhoA-ROCK-LIMK-Cof signaling pathway. Phosphorylated cofilin loses its severing activity toward F-actin microfilaments, which causes tension in the actin cytoskeleton. Reduction of FAs and F-actin dynamics blocks neurite sprouting. $\beta$ I integrin overactivity is further fueled by an excess of fibronectin in the surrounding milieu of PrPC-deficient neuroectodermal stem cells, originating from the upregulation of fibronectin gene transcription.

Abbreviations: PrPC, cellular prion protein; Cav-I, caveolin-I; Cof, cofilin; FA, focal adhesion; F-actin, fibrillar actin; G-actin, globular actin; ROCK, RhoA-associated coiledcoil containing kinases, or Rho kinases.

recycling of FA components necessary for neurite formation and outgrowth. Thus, the presence of $\operatorname{PrP}^{\mathrm{C}}$ appears essential for the fine-tuned regulation of FA stability and dynamics in neural stem cells, ${ }^{15,51}$ a prerequisite for the onset of neuronal polarity accompanying neuronal differentiation.

Beyond the impact on neuritogenesis, alteration of FA dynamics caused by the absence of $\operatorname{PrP}^{\mathrm{C}}$ would also affect proliferation and migration of neuronal stem cells, since these two events were shown to depend on the fine-tuning of FA stability. ${ }^{55,56}$ Accordingly, it was shown in vivo that neuronal progenitors of PrP knockout mice display reduced proliferation capacities. ${ }^{35}$

$\mathrm{PrP}^{\mathrm{C}}$ depletion in $1 \mathrm{C} 11$ neuroectodermal stem cells also affects the structure and dynamics of the actin cytoskeleton. Upon $\mathrm{PrP}^{\mathrm{C}}$ silencing, actin fibers have lost their parallel orientation, and their stability is greatly increased, compared with $\mathrm{PrP}^{\mathrm{C}}$ expressing $1 \mathrm{C} 11$ precursor cells. ${ }^{15}$ Thus, $\mathrm{PrP}^{\mathrm{C}}$ exerts a regulatory function on the organization and turnover of the actin meshwork in neuronal stem cells ${ }^{15}$ (Figure 1). $\operatorname{PrP}^{\mathrm{C}}$ indirectly promotes the severing of actin microfilaments through negative control of RhoA-GTPase signaling and notably the RhoA-Rho-associated kinase (ROCK)-LIMK1 and 2-cofilin signaling pathway, ${ }^{15}$ known to play a central part in neuritogenesis. ${ }^{57-61}$ By downregulating the signaling activity of the RhoA-ROCK-LIMK1 and 2 cascade, $\operatorname{PrP}^{\mathrm{C}}$ maintains cofilin in a poorly phosphorylated state, ${ }^{15}$ which in turn triggers the active conversion of F-actin into G-actin ${ }^{62,63}$ and thereby renders neuronal stem cells competent for neuritogenesis. The interplay between $\operatorname{PrP}^{\mathrm{C}}$ and $\beta 1$ integrins may favor relaxed actin stress fibers, which can rapidly disintegrate when neurite buds start forming in differentiating neurons. Indeed, actin turnover and FA dynamics are 
functionally related. $\beta 1$ integrin-induced FAK overactivation in PrPull-cells may trigger the recruitment and activation of Rho guanine nucleotide exchange factors, a class of proteins that switch on small G-RhoA proteins. ${ }^{64,65}$ Excessive mobilization of these factors would lead to overactivation of the RhoA-ROCK-LIMK1 and 2-cofilin pathway, the formation of tensed actin cytoskeleton with reduced turnover, and impairment of neurite sprouting. Alternatively, overstimulation of the RhoA-ROCK-LIMK1 and 2-cofilin cascade could also account for the increased stability of FAs, since RhoA-induced cell contractility was shown to increase the phosphorylation level of FA protagonists, leading to enhanced adhesion maturation. ${ }^{66,67}$

\section{Neurite sprouting also depends on PrPC-dependent control of fibronectin expression}

The nature and concentration of ECM components as well as the three-dimensional organization of ECM are known to influence the differentiation properties of neuronal progenitors. ${ }^{68}$ The ECM environment that permits neuronal differentiation was shown to differ according to the neuron type. ${ }^{69,70}$ Depletion of $\mathrm{PrP}^{\mathrm{C}}$ in $1 \mathrm{C} 11$ neuronal stem cells is associated with changes in the ECM, with an enrichment of secreted fibronectin surrounding $\mathrm{PrP}^{\text {null }}$-cells. The increase in secreted fibronectin level originates from enhanced fibronectin gene transcription. ${ }^{15}$ Since fibronectin is a main $\beta 1$ integrin ligand, $\operatorname{PrP}^{\mathrm{C}}$-mediated control of fibronectin expression in neuronal stem cells is critical for neurite sprouting and neuronal differentiation (Figure 1). Artificially enhancing the density of fibronectin in the environment of $\mathrm{PrP}^{\mathrm{C}}$ expressing $1 \mathrm{C} 11$ precursor cells (by coating increasing levels of fibronectin on culture dishes) hence impairs the initiation of neurites in a concentration-dependent manner. A fibronectin-induced defect of neurite formation originates from reduced turnover of FAs and overactivation of the RhoAROCK-LIMK1 and 2-cofilin signaling pathway, and thereby mimics $\operatorname{PrP}^{\mathrm{C}}$ deficiency. ${ }^{15}$

Of note, the increase in fibronectin level may change the structure of ECM through the conversion of soluble fibronectin into fibrillar fibronectin. ${ }^{18}$ The formation of fibrillar fibronectin would be catalyzed directly by $\beta 1$ integrins through their conformational changes induced by the binding of fibronectin to $\beta 1$ integrins (outside-in signaling). ${ }^{71}$ Alternatively, the increase in actin contractility triggered by the elevation of fibronectin level would also provoke the activation of $\beta 1$ integrins (inside-out signaling) and subsequent conversion of soluble fibronectin into fibrillar fibronectin. ${ }^{72}$ In turn, changes in fibronectin organization in the environment of $\mathrm{PrP}^{\mathrm{C}}$ depleted cells in combination with tensed actin would sustain $\beta 1$ integrin clustering and favor the conversion of dynamic FAs into static fibrillar adhesion contacts, ${ }^{73}$ thus contributing to neurite sprouting failure.

How $\mathrm{PrP}^{\mathrm{C}}$ exerts a transcriptional control on fibronectin expression level remains unclear. The cAMP-responsive element binding (CREB) transcription factor is assumed to pilot fibronectin gene expression. ${ }^{74,75} \mathrm{CREB}$ is a downstream target in the $\operatorname{PrP}^{\mathrm{C}}$ signaling pathway that promotes the expression of Egr-1 and $c$-fos immediate early genes in $1 \mathrm{C} 11$ precursor cells, underlying a potential role of $\mathrm{PrP}^{\mathrm{C}}$ in the survival, proliferation, and differentiation of neuronal stem cells. ${ }^{31}$ The coupling of $\mathrm{PrP}^{\mathrm{C}}$ to the CREB transcription factor may finely adjust the level of fibronectin in the microenvironment of neural stem cells, thus rendering cells competent for neuritogenesis. Of note, CREB is also controlled by $\beta 1$ integrin signaling. ${ }^{76}$ We may hypothesize overactivation of CREB activity downstream from $\beta 1$ integrins in $\mathrm{PrP}^{\text {null }}$-cells, leading to excessive fibronectin expression. In agreement, pharmacological inhibition of CREB lowers the fibronectin mRNA level in PrPnull-1C11 cells (our unpublished data). Oversecreted fibronectin would in turn self-sustain $\beta 1$ integrin activation and induce vicious circle conditions that impair neurite onset.

As a whole, these data argue for a role of $\mathrm{PrP}^{\mathrm{C}}$ in neurite sprouting. Endogenous expression of $\mathrm{PrP}^{\mathrm{C}}$ is necessary for regulating the level of ECM fibronectin, the clustering and activation of $\beta 1$ integrins, and the turnover of FAs and actin microfilaments via RhoA-GTPase signaling. $\operatorname{PrP}^{\mathrm{C}}$-dependent optimal dynamics of FAs and actin cytoskeleton render neuronal stem cells competent to respond to neuronal inducers and to develop neurites (Figure 1).

\section{PrPC and neurite outgrowth}

Apart from its contribution to the initial phase of neuritogenesis, $\mathrm{PrP}^{\mathrm{C}}$ also takes part in the outgrowth of neurites. This role of $\mathrm{PrP}^{\mathrm{C}}$ was initially supported by a set of experiments indicating that: (1) during mouse embryogenesis, $\operatorname{PrP}^{\mathrm{C}}$ is mainly detected in elongating axons; ${ }^{77}$ (2) neuronal differentiation and neurite outgrowth are displayed more slowly in primary cultures of neuronal progenitors derived from $\mathrm{PrP}^{-/-}$mice than from wild type mice; $;^{35,78,79}$ and (3) neurites of cultured hippocampal neurons from $\mathrm{PrP}^{-/-}$mice are shorter than those of $\mathrm{PrP}^{\mathrm{C}}$ expressing cells. ${ }^{80}$ In these paradigms, $\mathrm{PrP}^{\mathrm{C}}$ depletion alters neuritogenesis but does not cancel the acquisition of neuronal polarity. As mentioned before, this likely underlines 
the occurrence of compensatory mechanisms for the lack of $\mathrm{PrP}^{\mathrm{C}}$ in mice that permit neurite sprouting but do not allow the full execution of the neuritogenesis process. Based on these observations the concept emerges that $\operatorname{PrP}^{\mathrm{C}}$ facilitates neurite outgrowth along neuronal differentiation. ${ }^{79}$

\section{A set of $\operatorname{PrPC}$ partners sustains its facilitator role in neurite outgrowth}

The facilitator role of $\mathrm{PrP}^{\mathrm{C}}$ towards neurite outgrowth depends on its interactions with a set of distinct partners, reflecting the dynamic scaffolding function of $\mathrm{PrP}^{\mathrm{C}}$ according to its immediate membrane environment. ${ }^{21}$ By interacting with ECM components, soluble ligands, and/or neighboring cell surface proteins, $\mathrm{PrP}^{\mathrm{C}}$ functions as a dynamic platform for the assembly of various signaling modules orchestrating neurite elongation.

A first ligand identified is laminin, ${ }^{81}$ a protein of the ECM and a major constituent of the neuronal basal lamina. The $\mathrm{PrP}^{\mathrm{C}}$-laminin interaction was shown to sustain neuritogenesis: competition experiments using $\mathrm{PrP}^{\mathrm{C}}$ antibodies or laser inactivation of cell surface $\operatorname{PrP}^{\mathrm{C}}$ interfere with the laminindependent neurite outgrowth of PC12 cells. ${ }^{82}$ For instance, binding of laminin- $\gamma 1$ chain to $\operatorname{PrP}^{\mathrm{C}}$ allows the recruitment and association of $\operatorname{PrP}^{\mathrm{C}}$ with group I metabotropic glutamate receptors (mGluR1-5), and thus the formation of a multicomponent complex that transduces intracellular signals for neurite outgrowth in primary hippocampal neurons. ${ }^{83,84}$ In dorsal root neurons, $\mathrm{PrP}^{\mathrm{C}}$ interaction with vitronectin, another component of the ECM, is also shown to favor axonal growth through a $\beta 3$ integrin dependent mechanism. ${ }^{14}$

Several membrane proteins were also reported to influence $\mathrm{PrP}^{\mathrm{C}}$-facilitated neuritogenesis. This includes $\operatorname{PrP}^{\mathrm{C}}$ itself, because exposure of primary cultures of post-natal cerebellar neurons to dimers of recombinant $\mathrm{PrP}^{\mathrm{C}}$, mimicking transacting $\mathrm{PrP}^{\mathrm{C}}$ originating from neighboring cells or exosomes, ${ }^{85}$ sustains neurite outgrowth. ${ }^{33}$ Kanaani et al further showed that incubation of cultured hippocampal neurons with recombinant $\operatorname{PrP}^{\mathrm{C}}$ induces rapid polarization and the development of synapses.$^{80}$ Recently, such transacting $\mathrm{PrP}^{\mathrm{C}}-\mathrm{PrP}^{\mathrm{C}}$ interaction was shown to positively influence neurite outgrowth of hippocampal neurons by enhancing the formation of a co-cluster between $\operatorname{PrP}^{\mathrm{C}}$ and the raft-associated reggie protein (also called flotillin). The association between $\mathrm{PrP}^{\mathrm{C}}$ and reggie protein pilots the trafficking and cargomediated delivery of $\mathrm{N}$-cadherins to the growth cone as well as elongating axons. ${ }^{86}$ Another membrane protein candidate is the neural cell adhesion molecule (NCAM). $\mathrm{PrP}^{\mathrm{C}}$ interacts with NCAM and stabilizes NCAM in lipid rafts.
Disruption of the $\mathrm{PrP}^{\mathrm{C}}-\mathrm{NCAM}$ interaction impairs neurite outgrowth of cultured hippocampal neurons stimulated by exogenous $\mathrm{PrP}^{\mathrm{C}} .{ }^{87}$

Stress-inducible protein-1 (STI-1), a co-chaperone that associates with Hsp70 and Hsp90, ${ }^{88}$ is a soluble trophic factor released in the extracellular milieu by astrocytes. ${ }^{89}$ The interaction of soluble STI-1 with $\mathrm{PrP}^{\mathrm{C}}$ has been shown to influence neurite outgrowth of hippocampal neurons. ${ }^{90,91}$ The binding of STI- 1 to $\operatorname{PrP}^{\mathrm{C}}$ recruits and activates the $\alpha 7$ nicotinic acetylcholine receptor $(\alpha 7 \mathrm{nAChR})$ that transduces neurite outgrowth signals. ${ }^{91}$ Santos et al further documents that simultaneous binding of the STI- 1 and laminin- $\gamma 1$ chain to $\operatorname{PrP}^{\mathrm{C}}$ promotes a synergistic activation of $\alpha 7 \mathrm{nAChR}$ and mGluR1-5, which potentiates axonal growth of dorsal root ganglia neurons. ${ }^{92}$

Although $\operatorname{PrP}^{\mathrm{C}}$ is widely assumed to facilitate neurite outgrowth, one study illustrates that $\mathrm{PrP}^{\mathrm{C}}$ exerts the opposite role depending on the neuron type and $\mathrm{PrP}^{\mathrm{C}}$ partner involved. ${ }^{93}$ Indeed, $\mathrm{PrP}^{\mathrm{C}}$ is shown to negatively modulate in vivo and in vitro neurite outgrowth of neurons from the central nervous system through the interaction with plasma membrane contactin-associated protein (CaspR). ${ }^{93} \mathrm{CaspR}$ is an adhesion molecule required for the formation of axoglial paranodal junctions surrounding Ranvier nodes in myelinated axons. ${ }^{94-96} \mathrm{PrP}^{\mathrm{C}}-\mathrm{C}$-CaspR interaction inhibits the shedding of CaspR by the Reelin protease, ${ }^{97}$ and thereby triggers the accumulation of CaspR at the cell surface of neurons, which exacerbates the inhibitory role of CaspR on neurite outgrowth. ${ }^{93}$

By interacting with distinct membrane partners and ligands, $\operatorname{PrP}^{\mathrm{C}}$ influences neurite elongation. How $\mathrm{PrP}^{\mathrm{C}}$ dependent downstream signaling controls the remodeling of cell cytoskeleton that accompanies neurite outgrowth, remains unresolved however. Because actin and the dynamics of FAs also play a central role in neurite elongation, an attractive hypothesis is that the signaling modules scaffolded by $\operatorname{PrP}^{\mathrm{C}}$ at the plasma membrane of elongating neurites participate in neuritogenesis.

\section{Are Rho-GTPases the executive machinery through which PrPC takes part in neurite outgrowth?}

$\mathrm{PrP}^{\mathrm{C}}$ role in neurite outgrowth may involve its signaling function since the inhibition of $\mathrm{PrP}^{\mathrm{C}}$-controlled signaling intermediates, ie, Src kinases, including the p59Fyn tyrosine kinase, ${ }^{28}$ PKC or PI3 kinase, ${ }^{34}$ partially or fully abolishes neurite outgrowth. ${ }^{33,80}$ Nevertheless, activation of p59Fyn in neurite outgrowth also originates from the interaction of $\mathrm{PrP}^{\mathrm{C}}$ 
with NCAM. ${ }^{87}$ Whether Fyn activation mediated by $\mathrm{PrP}^{\mathrm{C}}$ $\mathrm{PrP}^{\mathrm{C}}$ or $\mathrm{PrP}^{\mathrm{C}}-\mathrm{NCAM}$ interaction facilitates neurite outgrowth by acting on actin microfilaments dynamics remains unknown. The Rho regulatory proteins, p190RhoGAP (GTPase-activating protein), are major regulators of RhoGTPase-mediated actin reorganization in neuronal growth cone. By transducing signals downstream from Src kinases and NCAM, p190RhoGAP contributes to axon outgrowth. ${ }^{17}$ Besides, Rho-GTPases are signaling intermediates coupled to other $\operatorname{PrP}^{\mathrm{C}}$ binding partners, including laminin/laminin receptor, reggie/flotillin, and mGluR..$^{17,98,99}$ We may propose that the functional interaction between $\mathrm{PrP}^{\mathrm{C}}$ and its partners modulates Rho-GTPase signaling and thereby optimizes actin remodeling necessary for neurite outgrowth (Figure 2).

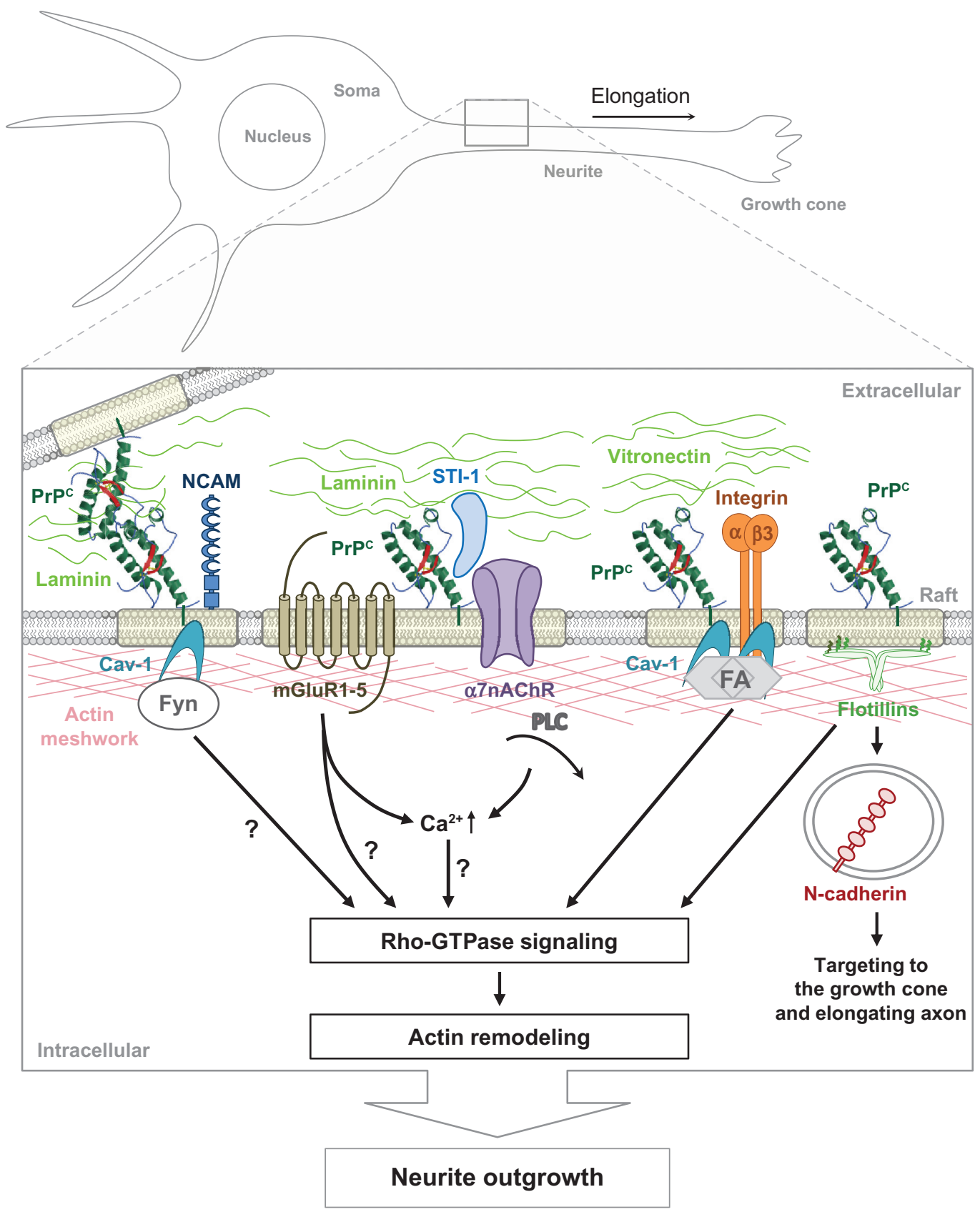

Figure $2 \mathrm{PrPC}^{\mathrm{C}}$ facilitates neurite outgrowth by fine-tuning the signaling activity of plasma membrane multiprotein complexes. The facilitator role of PrPC towards neurite outgrowth relies on the capacity of $\mathrm{PrPC}^{\mathrm{C}}$ to interact with multiple partners (laminin and vitronectin ECM components; PrPC, NCAM, reggie/flotillin, mGluRI-5, $\alpha 7 n A C h R$ plasma membrane proteins; soluble ligands such as STI-I) within raft microdomains and to recruit diverse signaling pathways. By orchestrating these signaling networks, PrPC would favor actin remodeling necessary for neurite outgrowth.

Abbreviations: Cav-I, caveolin-I; ECM, extracellular matrix; FA, focal adhesion; NCAM, neural cell adhesion molecule; mGluR I-5, group I metabotropic glutamate receptors; STI-I, stress inducible protein I; $\alpha 7 n A C h R, \alpha 7$ nicotinic acetylcholine receptor; PLC, phospholipase C; PrPC, cellular prion protein; ?, functional link is not yet determined. 
Finally, the increase in calcium concentration triggered by the interaction of $\mathrm{PrP}^{\mathrm{C}}$ with laminin- $\gamma 1$ or STI-1, and subsequent activation of mGluR $1-5$ or $\alpha 7 \mathrm{nAChR}$, respectively, ${ }^{92}$ also likely contributes to neurite elongation through cytoskeletal rearrangements induced by Rho-GTPases. ${ }^{100}$

These combined data indicate that the facilitator role of $\mathrm{PrP}^{\mathrm{C}}$ towards neurite outgrowth depends on the neuron type and relies on the capacity of $\mathrm{PrP}^{\mathrm{C}}$ to engage multiple partners (laminin and vitronectin ECM components; $\operatorname{PrP}^{\mathrm{C}}$, NCAM, reggie, mGluR, $\alpha 7 \mathrm{nAChR}$, and CaspR membrane proteins; soluble ligands such as STI-1) in multiprotein complexes and to recruit promiscuous signaling pathways. ${ }^{21}$ Depending on the partners involved and the stoichiometric equilibria between $\operatorname{PrP}^{\mathrm{C}}$ and its partners, $\operatorname{PrP}^{\mathrm{C}}$ mainly acts positively on neurite elongation, but may also exert the opposite action.

\section{$\mathrm{PrPC}^{\mathrm{C}}$ implication in neurite maintenance}

Once neurons have reached their terminal stage of differentiation and acquired their polarized morphology, it is suspected that $\mathrm{PrP}^{\mathrm{C}}$ positively acts on the maintenance and integrity of the axon and dendrites. Laser-mediated inactivation of cell surface $\mathrm{PrP}^{\mathrm{C}}$ promotes neurite retraction of differentiated PC12 cells. ${ }^{82}$ In line with this observation, our unpublished data indicate that transient siRNA-mediated $\operatorname{PrP}^{\mathrm{C}}$ silencing in fully differentiated $1 \mathrm{C} 11$-derived serotonergic $\left(1 \mathrm{C} 11^{5-\mathrm{HT}}\right)$ or noradrenergic $\left(1 \mathrm{C} 11^{\mathrm{NE}}\right)$ neuronal cells triggers neurite retraction. The mechanisms through which $\operatorname{PrP}^{\mathrm{C}}$ influences the stability of neuronal polarity have been studied less than those sustaining neurite sprouting and outgrowth, however.

In fully differentiated $1 \mathrm{C} 11^{5-\mathrm{HT}}$ and $1 \mathrm{C} 11^{\mathrm{NE}}$ neuronal cells, two $\operatorname{PrP}^{\mathrm{C}}$ interactors, the tissue nonspecific alkaline phosphatase (TNAP) and $\beta$-dystroglycan, ${ }^{101,102}$ may both take part in the maintenance of neurites. The restriction of TNAP expression ${ }^{101}$ and $\mathrm{PrP}^{\mathrm{C}}$-controlled $\beta$-dystroglycan cleavage by matrix metalloproteinase type 9 (MMP-9) ${ }^{31}$ to mature 1C11-derived neuronal cells may account for the specific contribution of TNAP and $\beta$-dystroglycan to neurite maintenance. These neurospecific interactions underline that $\mathrm{PrP}^{\mathrm{C}}$ interactome and coupled effectors differ between neuronal stem cells and fully differentiated neurons. The recruitment of $\mathrm{PrP}^{\mathrm{C}}$ in multiprotein complexes, which are specific to the stem cell stage or the neuronal context, may depend on different lipid-raft compositions, the engagement of distinct $\mathrm{PrP}^{\mathrm{C}}$ isoforms, ${ }^{103}$ variations of the composition and structure of the ECM surrounding neuronal stem cells and neurons, or changes in membrane fluidity that determine the dynamics of interaction between partners.

\section{Functional interactions between $\operatorname{PrPC}$, TNAP, and phosphorylated laminin maintain neurite extensions}

Our work establishes that in rafts of fully differentiated $1 \mathrm{C} 11^{5-\mathrm{HT}}$ and $1 \mathrm{C} 11^{\mathrm{NE}}$ neuronal cells, $\operatorname{PrP}^{\mathrm{C}}$ interacts with TNAP, ${ }^{101}$ an enzyme mainly known for its role in bone mineralization. In polarized neuronal cells, TNAP acts as an ecto-phosphatase that catalyzes the dephosphorylation of laminin, which in turn allows $\operatorname{PrP}^{\mathrm{C}}$ to interact with laminin. ${ }^{101}$ The onset of such a functional ternary $\mathrm{PrP}^{\mathrm{C}} / \mathrm{TNAP} /$ laminin complex sustains the stability of neuronal polarity (Figure 3). Accordingly, pharmacological inhibition of TNAP activity promotes the phosphorylation of laminin, which thus abrogates $\mathrm{PrP}^{\mathrm{C}}$ interaction with laminin. Disintegration of the $\mathrm{PrP}^{\mathrm{C}} /$ laminin/TNAP complex in rafts of $1 \mathrm{C} 11$-derived neuronal cells is accompanied by neurite retraction (our unpublished data). This finding is in line with previous data showing that disruption of the $\mathrm{PrP}^{\mathrm{C}}$-laminin interaction in differentiated PC12 cells triggers neurite retraction. ${ }^{82}$ We may envision that destabilization of the $\mathrm{PrP}^{\mathrm{C}} /$ laminin interaction upon laminin phosphorylation in mature neurons corrupts Rho-GTPase signaling ${ }^{17}$ and favors the severing of neurite sheathing actin microfilaments, thereby leading to neurite instability and retraction.

\section{Does $\mathrm{PrPC}$-dependent regulation of $\beta$-dystroglycan cleavage by MMP-9 partake in neurite maintenance?}

$\mathrm{PrP}^{\mathrm{C}}$-mediated stability of neurites may also originate from $\operatorname{PrP}^{\mathrm{C}}$ interaction with $\beta$-dystroglycan, ${ }^{102}$ a transmembrane protein that forms a bridge from the ECM (notably laminin) to the cell cytoskeleton; the cleavage of this protein triggers a loss of cell adhesion to its substratum. ${ }^{104,105}$ Our work establishes that, in neurites of fully differentiated $1 \mathrm{C} 11^{5-\mathrm{HT}}$ serotonergic neuronal cells, $\operatorname{PrP}^{\mathrm{C}}$ signaling protects $\beta$-dystroglycan from cleavage by the matrix metalloproteinase MMP-9 by repressing transcription of the MMP-9 encoding gene and inhibiting MMP-9 enzymic activity. ${ }^{31} \mathrm{PrP}^{\mathrm{C}}$ interaction and protection of $\beta$-dystroglycan may thus enhance the interaction between $\beta$-dystroglycan and ECM laminin. ${ }^{105}$ This action would contribute to the stability of neurites by maintaining the connection between laminin and the actin meshwork through $\beta$-dystroglycan (Figure 3). 


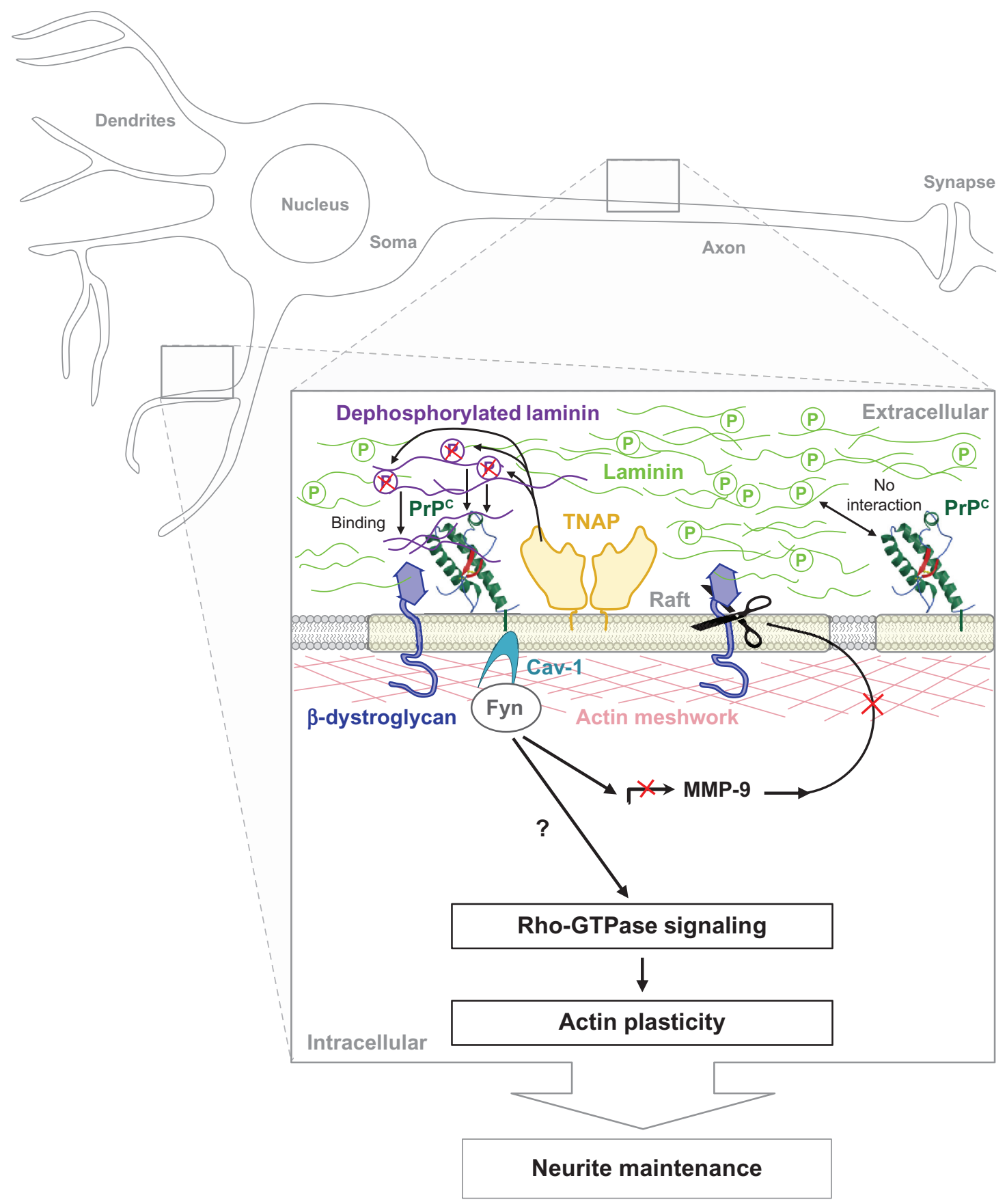

Figure 3 PrPC contributes to the maintenance of neurites in mature neurons. In fully differentiated neuronal cells, PrPC interacts with TNAP. TNAP catalyzes dephosphorylation of ECM laminin, which then binds to PrPC . The formation of a neurospecific ternary complex between $\operatorname{PrPC}$, TNAP, and non-phosphorylated laminin sustains the PrPC role in neurite stability. PrPC-mediated control of $\beta$-dystroglycan cleavage by MMP-9 may also account for the role of PrPC in neurite maintenance. By downregulating MMP-9 expression, $\operatorname{PrPC}$ protects $\beta$-dystroglycan from cleavage by MMP-9, which would in turn stabilize the connection between ECM laminin and actin cytoskeleton. Abbreviations: Cav-I, caveolin-I; ECM, extracellular matrix; PrPC, cellular prion protein; TNAP, tissue nonspecific alkaline phosphatase; MMP-9, matrix metalloproteinase type 9; ?, functional link is not yet determined.

\section{Conclusion}

This review illustrates how the cellular prion protein $\operatorname{PrP}^{\mathrm{C}}$ takes part in the three steps of neuritogenesis: (1) the initiation of neurite formation or neurite sprouting; (2) the outgrowth of neurites; and (3) the stability and maintenance of neuronal polarity. In future, this particular role of $\mathrm{PrP}^{\mathrm{C}}$ related to the acquisition and the stability of neuronal polarity should be addressed in prion diseases. In neurodegenerative diseases, synapse disconnection as well as retraction and degeneration of axons have been widely recognized as early events in the neurodegenerative process ${ }^{106}$ and likely account for behavioral and cognitive impairments observed in patients. ${ }^{107,108} \mathrm{In}$ prion 
diseases, it is now clearly established that corruption of $\mathrm{PrP}^{\mathrm{C}}$ associated functions by pathogenic prions $\left(\mathrm{PrPsc}^{\mathrm{Sc}}\right)$ in neurons induces neurodegeneration. ${ }^{19}$ Whether $\mathrm{PrP}^{\mathrm{Sc}}$ triggers a loss-offunction of $\mathrm{PrP}^{\mathrm{C}}$ upon its conversion into $\mathrm{PrP}^{\mathrm{Sc}}$ or promotes a gain-of-function upon $\mathrm{PrP}^{\mathrm{Sc}}$ interaction with $\mathrm{PrP}^{\mathrm{C}}$, or both, is still debated. In any case, $\mathrm{PrP}^{\mathrm{Sc}}$ would induce disintegration of multiprotein complexes involving $\mathrm{PrP}^{\mathrm{C}}$ and its partners. Because of the critical role of $\mathrm{PrP}^{\mathrm{C}}$ in the implementation of neurites and stability of axon and dendrites, it is conceivable that prion infection disturbs the $\mathrm{PrP}^{\mathrm{C}}$-fine-tuned functional relationship between the ECM, and cytoskeleton dynamics, and thereby threatens neuronal connectivity and integrity of neuronal networks. The identification of $\operatorname{PrP}^{\mathrm{C}}$-controlled signaling pathways involved in neuritogenesis that are corrupted by $\mathrm{PrP}^{\mathrm{Sc}}$ may help to define novel therapeutic strategies towards prion diseases.

\section{Acknowledgements}

Aurélie Alleaume-Butaux is supported by the DIM Mal Inf (Région Ile-de-France). Our work on prion biology is funded by the Agence Nationale de la Recherche (ANR) and INSERM.

\section{Disclosure}

The authors declare that they have no conflicts of interest in this work.

\section{References}

1. da Silva JS, Dotti CG. Breaking the neuronal sphere: regulation of the actin cytoskeleton in neuritogenesis. Nat Rev Neurosci. 2002;3(9):694-704.

2. Witte H, Bradke F. The role of the cytoskeleton during neuronal polarization. Curr Opin Neurobiol. 2008;18(5):479-487.

3. Cingolani LA, Goda Y. Actin in action: the interplay between the actin cytoskeleton and synaptic efficacy. Nat Rev Neurosci. 2008;9(5): 344-356.

4. Witte $\mathrm{H}$, Neukirchen D, Bradke F. Microtubule stabilization specifies initial neuronal polarization. J Cell Biol. 2008;180(3):619-632.

5. Gupton SL, Gertler FB. Integrin signaling switches the cytoskeletal and exocytic machinery that drives neuritogenesis. Dev Cell. 2010;18(5): $725-736$.

6. Lee H, Van Vactor D. Neurons take shape. Curr Biol. 2003;13(4): R152-R161.

7. Escalante M, Courtney J, Chin WG, et al. Phosphorylation of c-Crk II on the negative regulatory Tyr 222 mediates nerve growth factor-induced cell spreading and morphogenesis. J Biol Chem. 2000;275(32): 24787-24797.

8. Teng KK, Courtney JC, Henegouwen PB, Birge RB, Hempstead BL. Dissociation of NGF induced signal transduction from neurite elongation by expression of a mutant adaptor protein v-Crk in PC12 cells. Mol Cell Neurosci. 1996;8(2-3):157-170.

9. Aoki K, Nakamura T, Matsuda M. Spatio-temporal regulation of Rac1 and Cdc42 activity during nerve growth factor-induced neurite outgrowth in PC12 cells. J Biol Chem. 2004;279(1):713-719.

10. Encinas M, Iglesias M, Llecha N, Comella JX. Extracellular-regulated kinases and phosphatidylinositol 3-kinase are involved in brain-derived neurotrophic factor-mediated survival and neuritogenesis of the neuroblastoma cell line SH-SY5Y. J Neurochem. 1999;73(4):1409-1421.
11. Hartnick CJ, Staecker H, Malgrange B, et al. Neurotrophic effects of BDNF and CNTF, alone and in combination, on postnatal day 5 rat acoustic ganglion neurons. J Neurobiol. 1996;30(2):246-254.

12. Euteneuer S, Yang KH, Chavez E, et al. Glial cell line-derived neurotrophic factor (GDNF) induces neuritogenesis in the cochlear spiral ganglion via neural cell adhesion molecule (NCAM). Mol Cell Neurosci. 2012;54:30-43.

13. Freire E, Gomes FC, Jotha-Mattos T, Neto VM, Silva Filho FC, Coelho-Sampaio T. Sialic acid residues on astrocytes regulate neuritogenesis by controlling the assembly of laminin matrices. $J$ Cell Sci. 2004;117(Pt 18):4067-4076.

14. Hajj GN, Lopes MH, Mercadante AF, et al. Cellular prion protein interaction with vitronectin supports axonal growth and is compensated by integrins. J Cell Sci. 2007;120(Pt 11):1915-1926.

15. Loubet D, Dakowski C, Pietri M, et al. Neuritogenesis: the prion protein controls beta1 integrin signaling activity. Faseb J. 2012;26(2): 678-690.

16. Seidenfaden R, Krauter A, Hildebrandt $H$. The neural cell adhesion molecule NCAM regulates neuritogenesis by multiple mechanisms of interaction. Neurochem Int. 2006;49(1):1-11.

17. Brouns MR, Matheson SF, Settleman J. p190 RhoGAP is the principal Src substrate in brain and regulates axon outgrowth, guidance and fasciculation. Nat Cell Biol. 2001;3(4):361-367.

18. Geiger B, Bershadsky A, Pankov R, Yamada KM. Transmembrane crosstalk between the extracellular matrix - cytoskeleton crosstalk. Nat Rev Mol Cell Biol. 2001;2(11):793-805.

19. Aguzzi A, Calella AM. Prions: protein aggregation and infectious diseases. Physiol Rev. 2009;89(4):1105-1152.

20. Miele G, Alejo Blanco AR, Baybutt H, Horvat S, Manson J, Clinton M. Embryonic activation and developmental expression of the murine prion protein gene. Gene Expr. 2003;11(1):1-12.

21. Linden R, Martins VR, Prado MA, Cammarota M, Izquierdo I, Brentani RR. Physiology of the prion protein. Physiol Rev. 2008;88(2): 673-728.

22. Lucero HA, Robbins PW. Lipid rafts-protein association and the regulation of protein activity. Arch Biochem Biophys. 2004;426(2):208-224.

23. Sarnataro D, Campana V, Paladino S, Stornaiuolo M, Nitsch L, Zurzolo C. $\operatorname{PrP}(\mathrm{C})$ association with lipid rafts in the early secretory pathway stabilizes its cellular conformation. Mol Biol Cell. 2004;15(9): 4031-4042.

24. Taylor DR, Hooper NM. The prion protein and lipid rafts. Mol Membr Biol. 2006;23(1):89-99.

25. Lewis V, Hooper NM. The role of lipid rafts in prion protein biology. Front Biosci. 2011;16:151-168.

26. Brown DA, London E. Functions of lipid rafts in biological membranes. Annu Rev Cell Dev Biol. 1998;14:111-136.

27. Simons K, Toomre D. Lipid rafts and signal transduction. Nat Rev Mol Cell Biol. 2000;1(1):31-39.

28. Mouillet-Richard S, Ermonval M, Chebassier C, et al. Signal transduction through prion protein. Science. 2000;289(5486):1925-1928.

29. Schneider B, Mutel V, Pietri M, Ermonval M, Mouillet-Richard S, Kellermann O. NADPH oxidase and extracellular regulated kinases $1 / 2$ are targets of prion protein signaling in neuronal and nonneuronal cells. Proc Natl Acad Sci U S A. 2003;100(23):13326-13331.

30. Pradines E, Loubet D, Mouillet-Richard S, et al. Cellular prion protein coupling to TACE-dependent TNF-alpha shedding controls neurotransmitter catabolism in neuronal cells. J Neurochem. 2009; 110(3):912-923.

31. Pradines E, Loubet D, Schneider B, Launay JM, Kellermann O, MouilletRichard S. CREB-dependent gene regulation by prion protein: Impact on MMP-9 and beta-dystroglycan. Cell Signal. 2008;20(11):2050-2058.

32. Chiarini LB, Freitas AR, Zanata SM, Brentani RR, Martins VR, Linden R. Cellular prion protein transduces neuroprotective signals. EMBO J. 2002;21(13):3317-3326.

33. Chen S, Mange A, Dong L, Lehmann S, Schachner M. Prion protein as trans-interacting partner for neurons is involved in neurite outgrowth and neuronal survival. Mol Cell Neurosci. 2003;22(2):227-233. 
34. Schneider B, Pietri M, Pradines E, et al. Understanding the neurospecificity of Prion protein signaling. Front Biosci. 2011;16:169-186.

35. Steele AD, Emsley JG, Ozdinler PH, Lindquist S, Macklis JD. Prion protein $(\mathrm{PrPc})$ positively regulates neural precursor proliferation during developmental and adult mammalian neurogenesis. Proc Natl Acad Sci USA. 2006;103(9):3416-3421.

36. Zhang CC, Steele AD, Lindquist S, Lodish HF. Prion protein is expressed on long-term repopulating hematopoietic stem cells and is important for their self-renewal. Proc Natl Acad Sci U SA. 2006;103(7): 2184-2189.

37. Liang J, Pan Y, Zhang D, et al. Cellular prion protein promotes proliferation and G1/S transition of human gastric cancer cells SGC7901 and AGS. FASEB J. 2007;21(9):2247-2256.

38. Rambold AS, Muller V, Ron U, Ben-Tal N, Winklhofer KF, Tatzelt J. Stress-protective signalling of prion protein is corrupted by scrapie prions. EMBO J. 2008;27(14):1974-1984.

39. Mouillet-Richard S, Mutel V, Loric S, Tournois C, Launay JM, Kellermann O. Regulation by neurotransmitter receptors of serotonergic or catecholaminergic neuronal cell differentiation. J Biol Chem. 2000;275(13):9186-9192.

40. Mouillet-Richard S, Laurendeau I, Vidaud M, Kellermann O, Laplanche JL. Prion protein and neuronal differentiation: quantitative analysis of prnp gene expression in a murine inducible neuroectodermal progenitor. Microbes Infect. 1999;1(12):969-976.

41. Watanabe T, Yasutaka Y, Nishioku T, et al. Atorvastatin stimulates neuroblastoma cells to induce neurite outgrowth by increasing cellular prion protein expression. Neurosci Lett. 2012;531(2):114-119.

42. Shmerling D, Hegyi I, Fischer M, et al. Expression of amino-terminally truncated $\operatorname{PrP}$ in the mouse leading to ataxia and specific cerebellar lesions. Cell. 1998;93(2):203-214.

43. Young R, Passet B, Vilotte M, et al. The prion or the related Shadoo protein is required for early mouse embryogenesis. FEBS Lett. 2009; 583(19):3296-3300.

44. Malaga-Trillo E, Solis GP, Schrock Y, et al. Regulation of embryonic cell adhesion by the prion protein. PLoS Biol. 2009;7(3):e55.

45. Margadant C, Monsuur HN, Norman JC, Sonnenberg A. Mechanisms of integrin activation and trafficking. Curr Opin Cell Biol. 2011;23(5): 607-614.

46. Watts JC, Huo H, Bai Y, et al. Interactome analyses identify ties of $\mathrm{PrP}$ and its mammalian paralogs to oligomannosidic N-glycans and endoplasmic reticulum-derived chaperones. PLoS Pathog. 2009;5(10): e1000608.

47. Pantera B, Bini C, Cirri P, et al. PrPc activation induces neurite outgrowth and differentiation in PC12 cells: role for caveolin-1 in the signal transduction pathway. J Neurochem. 2009;110(1):194-207.

48. Mouillet-Richard S, Schneider B, Pradines E, et al. Cellular prion protein signaling in serotonergic neuronal cells. Ann NY Acad Sci. 2007;1096: 106-119.

49. Park JH, Ryu JM, Han HJ. Involvement of caveolin-1 in fibronectininduced mouse embryonic stem cell proliferation: role of FAK, RhoA, PI3K/Akt, and ERK 1/2 pathways. J Cell Physiol. 2011;226(1): 267-275.

50. Salani B, Briatore L, Contini P, et al. IGF-I induced rapid recruitment of integrin beta1 to lipid rafts is Caveolin-1 dependent. Biochem Biophys Res Commun. 2009;380(3):489-492.

51. Schrock Y, Solis GP, Stuermer CA. Regulation of focal adhesion formation and filopodia extension by the cellular prion protein (PrPC). FEBS Lett. 2009;583(2):389-393.

52. Legate KR, Wickstrom SA, Fassler R. Genetic and cell biological analysis of integrin outside-in signaling. Genes Dev. 2009;23(4): 397-418.

53. Zaidel-Bar R, Ballestrem C, Kam Z, Geiger B. Early molecular events in the assembly of matrix adhesions at the leading edge of migrating cells. J Cell Sci. 2003;116(Pt 22):4605-4613.

54. Thoumine O. Interplay between adhesion turnover and cytoskeleton dynamics in the control of growth cone migration. Cell Adh Migr. 2008;2(4):263-267.
55. Wozniak MA, Modzelewska K, Kwong L, Keely PJ. Focal adhesion regulation of cell behavior. Biochim Biophys Acta. 2004;1692(2-3): $103-119$.

56. Cox BD, Natarajan M, Stettner MR, Gladson CL. New concepts regarding focal adhesion kinase promotion of cell migration and proliferation. J Cell Biochem. 2006;99(1):35-52.

57. Bito H, Furuyashiki T, Ishihara H, et al. A critical role for a Rhoassociated kinase, p160ROCK, in determining axon outgrowth in mammalian CNS neurons. Neuron. 2000;26(2):431-441.

58. Kuhn TB, Meberg PJ, Brown MD, et al. Regulating actin dynamics in neuronal growth cones by $\mathrm{ADF} /$ cofilin and rho family GTPases. J Neurobiol. 2000;44(2):126-144.

59. Govek EE, Newey SE, Van Aelst L. The role of the Rho GTPases in neuronal development. Genes Dev. 2005;19(1):1-49.

60. Sfakianos MK, Eisman A, Gourley SL, et al. Inhibition of Rho via Arg and p190RhoGAP in the postnatal mouse hippocampus regulates dendritic spine maturation, synapse and dendrite stability, and behavior. J Neurosci. 2007;27(41):10982-10992.

61. Threadgill R, Bobb K, Ghosh A. Regulation of dendritic growth and remodeling by Rho, Rac, and Cdc42. Neuron. 1997;19(3): 625-634.

62. Arber S, Barbayannis FA, Hanser H, et al. Regulation of actin dynamics through phosphorylation of cofilin by LIM-kinase. Nature. 1998; 393(6687):805-809.

63. Yang N, Higuchi O, Ohashi K, et al. Cofilin phosphorylation by LIMkinase 1 and its role in Rac-mediated actin reorganization. Nature. 1998;393(6687):809-812.

64. Mitra SK, Hanson DA, Schlaepfer DD. Focal adhesion kinase: in command and control of cell motility. Nat Rev Mol Cell Biol. 2005;6(1): $56-68$.

65. Tomar A, Lim ST, Lim Y, Schlaepfer DD. A FAK-p120RasGAPp190RhoGAP complex regulates polarity in migrating cells. J Cell Sci. 2009;122(Pt 11):1852-1862.

66. Chrzanowska-Wodnicka M, Burridge K. Rho-stimulated contractility drives the formation of stress fibers and focal adhesions. $J$ Cell Biol. 1996;133(6):1403-1415.

67. Schoenwaelder SM, Burridge K. Bidirectional signaling between the cytoskeleton and integrins. Curr Opin Cell Biol. 1999;11(2): 274-286.

68. Ma W, Tavakoli T, Derby E, Serebryakova Y, Rao MS, Mattson MP. Cell-extracellular matrix interactions regulate neural differentiation of human embryonic stem cells. BMC Dev Biol. 2008;8:90.

69. Rogers SL, Letourneau PC, Palm SL, McCarthy J, Furcht LT. Neurite extension by peripheral and central nervous system neurons in response to substratum-bound fibronectin and laminin. Dev Biol. 1983;98(1): 212-220.

70. Guan W, Puthenveedu MA, Condic ML. Sensory neuron subtypes have unique substratum preference and receptor expression before target innervation. J Neurosci. 2003;23(5):1781-1791.

71. Wennerberg K, Lohikangas L, Gullberg D, Pfaff M, Johansson S, Fassler R. Beta 1 integrin-dependent and -independent polymerization of fibronectin. J Cell Biol. 1996;132(1-2):227-238.

72. Wu C, Keivens VM, O'Toole TE, McDonald JA, Ginsberg MH. Integrin activation and cytoskeletal interaction are essential for the assembly of a fibronectin matrix. Cell. 1995;83(5):715-724.

73. Pankov R, Cukierman E, Katz BZ, et al. Integrin dynamics and matrix assembly: tensin-dependent translocation of alpha(5)beta(1) integrins promotes early fibronectin fibrillogenesis. J Cell Biol. 2000;148(5): 1075-1090.

74. Bowlus CL, McQuillan JJ, Dean DC. Characterization of three different elements in the $5^{\prime}$-flanking region of the fibronectin gene which mediate a transcriptional response to cAMP. J Biol Chem. 1991;266(2): $1122-1127$.

75. Roman J, Ritzenthaler JD, Bechara R, Brown LA, Guidot D. Ethanol stimulates the expression of fibronectin in lung fibroblasts via kinasedependent signals that activate CREB. Am J Physiol Lung Cell Mol Physiol. 2005;288(5):L975-L987. 
76. Alenghat FJ, Tytell JD, Thodeti CK, Derrien A, Ingber DE. Mechanical control of cAMP signaling through integrins is mediated by the heterotrimeric Galphas protein. J Cell Biochem. 2009;106(4): $529-538$.

77. Sales N, Hassig R, Rodolfo K, et al. Developmental expression of the cellular prion protein in elongating axons. Eur J Neurosci. 2002;15(7): $1163-1177$.

78. Kuwahara C, Takeuchi AM, Nishimura T, et al. Prions prevent neuronal cell-line death. Nature. 1999;400(6741):225-226.

79. Barenco MG, Valori CF, Roncoroni C, Loewer J, Montrasio F, Rossi D. Deletion of the amino-terminal domain of the prion protein does not impair prion protein-dependent neuronal differentiation and neuritogenesis. J Neurosci Res. 2009;87(3):806-819.

80. Kanaani J, Prusiner SB, Diacovo J, Baekkeskov S, Legname G. Recombinant prion protein induces rapid polarization and development of synapses in embryonic rat hippocampal neurons in vitro. J Neurochem. 2005;95(5):1373-1386.

81. Graner E, Mercadante AF, Zanata SM, et al. Cellular prion protein binds laminin and mediates neuritogenesis. Brain Res Mol Brain Res. 2000;76(1):85-92.

82. Graner E, Mercadante AF, Zanata SM, Martins VR, Jay DG, Brentani RR. Laminin-induced PC-12 cell differentiation is inhibited following laser inactivation of cellular prion protein. FEBS Lett. 2000; 482(3):257-260.

83. Coitinho AS, Freitas AR, Lopes MH, et al. The interaction between prion protein and laminin modulates memory consolidation. Eur $J$ Neurosci. 2006;24(11):3255-3264.

84. Beraldo FH, Arantes CP, Santos TG, et al. Metabotropic glutamate receptors transduce signals for neurite outgrowth after binding of the prion protein to laminin gamma1 chain. Faseb J. 2011;25(1):265-279.

85. Fevrier B, Vilette D, Archer F, et al. Cells release prions in association with exosomes. Proc Natl Acad Sci U S A. 2004;101(26):9683-9688.

86. Bodrikov V, Solis GP, Stuermer CA. Prion protein promotes growth cone development through reggie/flotillin-dependent $\mathrm{N}$-cadherin trafficking. J Neurosci. 2011;31(49):18013-18025.

87. Santuccione A, Sytnyk V, Leshchyns'ka I, Schachner M. Prion protein recruits its neuronal receptor NCAM to lipid rafts to activate p59fyn and to enhance neurite outgrowth. $J$ Cell Biol. 2005;169(2):341-354.

88. Nicolet CM, Craig EA. Isolation and characterization of STI1, a stress-inducible gene from Saccharomyces cerevisiae. Mol Cell Biol. 1989;9(9):3638-3646.

89. Lima FR, Arantes CP, Muras AG, Nomizo R, Brentani RR, Martins VR. Cellular prion protein expression in astrocytes modulates neuronal survival and differentiation. $J$ Neurochem. 2007;103(6):2164-2176.

90. Zanata SM, Lopes MH, Mercadante AF, et al. Stress-inducible protein 1 is a cell surface ligand for cellular prion that triggers neuroprotection. Embo J. 2002;21(13):3307-3316.

91. Beraldo FH, Arantes CP, Santos TG, et al. Role of alpha7 nicotinic acetylcholine receptor in calcium signaling induced by prion protein interaction with stress-inducible protein 1. J Biol Chem. 2010;285(47): 36542-36550.

92. Santos TG, Beraldo FH, Hajj GN, et al. Laminin- $\gamma 1$ chain and stress inducible protein 1 synergistically mediate PrPC-dependent axonal growth via $\mathrm{Ca} 2+$ mobilization in dorsal root ganglia neurons. J Neurochem. 2013;124(2):210-223.
93. Devanathan V, Jakovcevski I, Santuccione A, et al. Cellular form of prion protein inhibits Reelin-mediated shedding of Caspr from the neuronal cell surface to potentiate Caspr-mediated inhibition of neurite outgrowth. J Neurosci. 2010;30(27):9292-9305.

94. Einheber S, Zanazzi G, Ching W, et al. The axonal membrane protein Caspr, a homologue of neurexin IV, is a component of the septate-like paranodal junctions that assemble during myelination. $J$ Cell Biol. 1997;139(6):1495-1506.

95. Scherer SS. Nodes, paranodes, and incisures: from form to function. Ann N Y Acad Sci. 1999;883:131-142.

96. Rios JC, Melendez-Vasquez CV, Einheber S, et al. Contactin-associated protein (Caspr) and contactin form a complex that is targeted to the paranodal junctions during myelination. $J$ Neurosci. 2000;20(22): 8354-8364.

97. Quattrocchi CC, Wannenes F, Persico AM, et al. Reelin is a serine protease of the extracellular matrix. J Biol Chem. 2002;277(1): 303-309.

98. Langhorst MF, Jaeger FA, Mueller S, Sven Hartmann L, Luxenhofer G, Stuermer CA. Reggies/flotillins regulate cytoskeletal remodeling during neuronal differentiation via $\mathrm{CAP} /$ ponsin and Rho GTPases. Eur J Cell Biol. 2008;87(12):921-931.

99. Schubert V, Da Silva JS, Dotti CG. Localized recruitment and activation of RhoA underlies dendritic spine morphology in a glutamate receptordependent manner. J Cell Biol. 2006;172(3):453-467.

100. Jin $\mathrm{M}$, Guan CB, Jiang YA, et al. Ca2+-dependent regulation of rho GTPases triggers turning of nerve growth cones. $J$ Neurosci. 2005;25(9):2338-2347.

101. Ermonval M, Baudry A, Baychelier F, et al. The cellular prion protein interacts with the tissue non-specific alkaline phosphatase in membrane microdomains of bioaminergic neuronal cells. PLoS One. 2009;4(8):e6497.

102. Keshet GI, Bar-Peled O, Yaffe D, Nudel U, Gabizon R. The cellular prion protein colocalizes with the dystroglycan complex in the brain. J Neurochem. 2000;75(5):1889-1897.

103. Ermonval M, Mouillet-Richard S, Codogno P, Kellermann O, Botti J. Evolving views in prion glycosylation: functional and pathological implications. Biochimie. 2003;85(1-2):33-45.

104. Yamada H, Saito F, Fukuta-Ohi H, et al. Processing of betadystroglycan by matrix metalloproteinase disrupts the link between the extracellular matrix and cell membrane via the dystroglycan complex. Hum Mol Genet. 2001;10(15):1563-1569.

105. Cavaldesi M, Macchia G, Barca S, Defilippi P, Tarone G, Petrucci TC. Association of the dystroglycan complex isolated from bovine brain synaptosomes with proteins involved in signal transduction. J Neurochem. 1999;72(4):1648-1655.

106. Brose N, O'Connor V, Skehel P. Synaptopathy: dysfunction of synaptic function? Biochem Soc Trans. 2010;38(2):443-444.

107. Arendt T. Synaptic degeneration in Alzheimer's disease. Acta Neuropathol. 2009;118(1):167-179.

108. Medana IM, Esiri MM. Axonal damage: a key predictor of outcome in human CNS diseases. Brain. 2003;126(Pt 3):515-530.
Cell Health and Cytoskeleton

\section{Publish your work in this journal}

Cell Health and Cytoskeleton is an international, peer-reviewed open access journal focusing on all aspects of cell structure and function contributing to normal physiology and cell health and exploring the pathogenesis of cell dysfunction leading to adverse conditions and disease in the organism. The journal welcomes papers covering original research,

\section{Dovepress}

basic science, reviews and evaluations, guidelines, expert opinion and commentary, case reports and extended reports. The manuscript management system is completely online and includes a very quick and fair peerreview system, which is all easy to use. Visit http://www.dovepress.com/ testimonials.php to read real quotes from published authors. 